\title{
Interactive Game Influences Based on Inquiry Learning Model Towards The Ability of Reading in Kindergarten in Padang
}

\author{
Rakimahwati \\ Early Childhood Education Department \\ Universitas Negeri Padang \\ Padang, Indonesia
}

\begin{abstract}
The purpose of this research is to identify the influence of interactive games based on inquiry learning model towards the ability of reading. This research method is experimental design with quashi experimental. The result showed that students in experimental class using interactive games based on inquiry learning models have a higher average compared than students in control class that use application-based games, so it is concluded that interactive games have an effect on developing reading skills in Kindergarten in Padang.
\end{abstract}

Keywords - interactive games; inquiry learning mode; children reading skill.

\section{INTRODUCTION}

Early Childhood Education is an early education after child born which can not be ignored, because early childhood can become as a container of self-development of child to be able to develop optimally according to characteristic of its development. The Regulation of the Minister of Education and Culture No. 137 of 2014 on the National Standard of Early Childhood Education in Chapter I Article I clause 10 states that Early Childhood Education is a coaching effort aimed for children from birth to age 6 (six) years conducted through the provision of stimuli education to help the growth and development of physical and spiritual so that children have readiness in entering further education.

Provision of these stimulus through education for children should be done comprehensively, meaning that children may not only have an intelligent brain, but also smart on other aspects of his life. Regulation of the Minister of National Education on the Early Childhood Education Standard number 137 of 2014 The Standard of Achievement of Child Development Chapter III Article 7, paragraph 3, that child development is an integration of moral, physical-motor, cognitive, language, and social-emotional

One aspect to be developed is language. The development of language in early childhood is very important because with the language children can communicate with members of the community, receive and convey information, understanding about story and retell it, children can recognize the objects around better, as well as things related to literacy. Regulation of the Minister of National Education on Early Childhood
Education Standards, states that the scope of language development is divided into three parts, namely: (1) accept the language; (2) express the language; And (3) literacy. Literacy includes the abilities, interests, passions, habits, and needs of reading and writing that are patterned and rooted in the daily life of the community.

For a child to read is the primary means to sharpen his curiosity. Reading is a process that involves a number of physical and mental activities such as recognizing letters and words, connecting them with sounds and their meanings, and drawing conclusions about the meaning of reading. Reading is a long process in stages starting from digesting and understanding symbols until the child can know the purpose of what he reads. Children who have good reading skills generally have a good ability to express thoughts, feelings and interactive actions with the environment. Reading in Kindergarten can be done with various models, methods, strategies and techniques, materials, media, and selection of activities appropriate for children.

Early childhood learning activities are often termed by playing while learning, learning while playing. Based on the guidance of the Minister of Education and Culture of the Republic of Indonesia number 146 of 2014 on the curriculum of 2013 Early Childhood Education in the learning guidelines, the principle that used in the early childhood learning process of the first part is learning through playing that children under the age of 6 are in play stage. Providing educational stimulation in the right way through play, can provide meaningful learning for children. This means without realizing all the play process by the child can have an impact on its development.

Optimal learning activities can be influenced by the media used, educators who have competence, parental involvement, and support from the community. The use of learning media for children is fun is very important to be noted. One of the media that can be used in this modern age is media technology.

Utilization of technology in the development of reading ability can be done by providing games that interest reading children. From the expert opinion states that at the age of 4-6 years children can already be taught to read. The age of 
Kindergarten has been able to view itself as a reader, giving meaning to the picture. Using three language systems, such as phonemes (semantics), semantics (meaning words), and syntax (word or sentence rules) and at Kindergarten age can already recognize the sounds of letters, the meaning of words, and the rules of words or phrases. Basic stage of reading the child is able to distinguish the pattern of letters, although not understood the meaning. The development of children's reading is stimulated from the beginning well then it will be good for the development of further reading.

Nowadays the development of science and technology so rapidly, and covers all aspects of human life. This can be seen from the various innovations created for the development of science and technology including the development of instructional media used to be interesting and varied especially for early childhood. One of the interesting media and can stimulate children's reading ability is interactive game. According to [1] game is an integral part of the child's world, even can be said is very important for the growth of children's intelligence. This study aims to determine how much influence of interactive games based on inquiry learning model of reading ability in Kindergarten in Padang.

Every experts have different definitions of reading. According to [2] states read is an integrated unity of activities that includes several activities such as recognizing letters and words, connecting with sounds and meaning, and drawing conclusions about the meaning of reading. [3] states that reading is not just reading, but this activity has a purpose, that is to get some new information. Behind the activity of reading, there are more specific goals, namely as pleasure, increase knowledge, and to be able to do a job. Reading aims to multiply various information or messages according to the type of reading selected. By reading will gain pleasure and increase knowledge.

Jeanne Chall in [4] states that there are five stages of reading ability development, namely: a) Basic Stage. The basic phase begins when the child begins to master the prerequisites of reading. The child has already distinguished the pattern of letters, although not yet understood the meaning of the word; B) Stage 1: The child is learning about the ability to "record" phonology. Phonological ability is used to translate symbols into sounds and words; C) Stage 2: The child has learned to read fluently; D) Stage 3: There is a term "learning to read" to "reading to learn". At this stage the child has been informed of written materials; E) Stage 4: The child can easily understand the various reading materials and draw conclusions from the reading. [5] there are several benefits of reading for infants and children, among them are: a) stimulating and developing their speaking skills; B) stimulate their memory and imagination; C) provide information about their surroundings; D) enrich their vocabulary; And E) introducing numbers, words, colors, and shapes.

Torrey in [6] states one of the principles of children's reading ability is how children are interested in reading activities, so this activity becomes a fun activity. The principles of children's reading ability are to familiarize the child with the pleasure and interest of reading by taking into account the characteristics of the child and through a playful reading game for the child.

It can be concluded that reading is an activity that translates signs and symbols, connects sounds and meanings and draws conclusions about the meaning of reading by providing interesting activities and can stimulate the memory and imagination of the child.

According to [7] the application of technology and education in the learning process is intended to make learning more effective, more efficient, more extensive, faster and more meaningful for the life of the learners. [8] states that the game is one means that can be used as a way for transformatting knowledges to children. Therefore, when someone plays a game, it means not just a game that can entertain or engage in a cheerful activity that is void of meaning, but more than that, the game played by anyone will have an educational meaning, even without the realization of the person who doing it.

Based on the above opinion it can be concluded that interactive games based on inquiry learning model can be used as a medium to develop children's easy reading ability and fun. Because interactive games provide a reciprocal relationship between games and children or between playmates. Interactive games involve the active participation of children thinking and finding letters that and / or words that are the same letter. Children who will find themselves (inquiry) in searching for similar letters and reading words that have the same letter prefix. So it is expected to have a sense of confidence and have a high social attitude when working in groups. This study aims to see the influence of interactive games based on inquiry learning model towards the ability of reading in indergarten in Padang.

\section{RESEARCH METHODS}

Based on the problems studied then this type of research is Experiment with quashi experiment research design. According to [9] experimental method is a research method used to find the effect of certain treatment against others in controlled conditions.

The population in this study is in kindergarten in Padang. Sampling technique conducted in this research is cluster sampling technique. According [9] cluster sampling (sampling area) is a technique used to determine the sample when the object to be studied or data source is very broad. To determine the data source, the sampling is based on the specified population area.

According to [10] validity is a measure that shows the levels of validity or validity of an instrument. A valid or valid instrument has high validity. Conversely, a less valid instrument means to it is have low validity. Test reliability is a measure of the accuracy of a test when it is tied to the same object. To determine the reliability of the test used Alpha formula that [10].

The data analysis technique used in this study is to compare the difference of two average values, so that it is done by t-test. For prerequisite hypothesis test is done 
normality test using Liliefors and Homogeneity test using Bartlett test. To be able to draw conclusion from result of research, hypothesis test by using $\mathrm{t}$ test. Before conducting $\mathrm{t}$ test, normality test and homogeneity test on the result of the research are done.

\section{RESULTS}

The result of children in experimental group and control group on pre-test obtained the average number of experimental group that is 62 . The control group average score is 59. Based on the data analysis that has been done that tcount is 0.842 with $\alpha 0.05$ (ttable $=2,1009$ ) with degrees of freedom $\mathrm{dk}(\mathrm{N} 1-1)+(\mathrm{N} 2-1)=18$. Thus tcount $<$ ttabel is $0.842<$ 2.1009 , then it can be said that the hypothesis Ha is rejected or Ho is accepted. It was concluded that there was no significant difference between reading ability of children in experimental group and control group. Then, based on the results of children's reading ability in the experimental group and the control group on the post-test obtained the average number of experimental group is 88 . The average number of control class is

76.5 .

The result of post-test data analysis has been done that tcount is 2,76442 compared with $\alpha 0,05$ (ttable $=2,10092$ ) with degree of freedom of $\mathrm{dk}(\mathrm{N} 1-1)+(\mathrm{N} 2-1)=18$. Thus tcount $>$ ttabel is $2.76442>2.10092$, it can be said that the hypothesis of $\mathrm{Ha}$ is accepted or Ho is rejected. It can be concluded that there is significant interactive Game based on inquiry learning model on reading ability in Kindergarten in Padang.

From the research that has been done by researcher, it can be seen the relationship of pre-test and post-test result. The result of pre-test shows that the average of experiment class is 62 and the control class average is 59. After the treatment is seen the post-test result of children's reading ability in the experimental class using interactive game based on inquiry learning model is increasing with average 88 Whereas in the control class is 76.5 by using application-based games. It can be concluded that the interactive game based on inquiry learning model has an effect on The ability of reading in Kindergarten in Padang.

\section{DISCUSSION}

Children 4 years old have vocabulary more than 4000 vocabulary and have been able to make simple sentences. [11] states that the development of early childhood language, they have been able to gather approximately 4000 to 6000 vocabulary, show attention to abstract words, and start using a few words. An important aspect developed during childhood is the ability to read. Through reading the child can know the letters and words and connect it with the sound. [2] states that reading is an integrated unity includes several activities such as recognizing letters and words, connecting with sounds and meaning, and drawing conclusions about the meaning of reading.

Interactive games based on inquiry learning model is a game based on inquiry which is done together (existence of reciprocal relationship) using digital technology (android). Through this game the child not only gives a sense of fun, but also can develop the process of thinking, action, interaction, and stimulate the child to ask. Interactive games are designed to develop reading skills, such as children can recognize and mention objects, children are able to say letters, children can find the same letter, children are able to mention words that have the same initial letter, and children can read the word. So that the interactive game based on inquiry learning model becomes one of the game that have an enormous influence in improving children's reading ability. The institute's policy on media and communications [12] in America or the American Academy of Pediatrics (AAP) Council on Communications and Media explains that high quality interactive media can benefit children in improving their social, language and readiness skills in school.

Researchers use interactive games in experimental groups and all children look enthusiastic and play the game spirit. In addition, children easily understand the intent in the game because interactive games provide reciprocal relationships so that children understand the commands in the game and interactive games are also it arranged out rewards such as great words, smart, and good for the success of the child who answered correctly, and the word motivation "try again" if the child replied Wrong. This is because the interactive gaming media provides an interesting and new look for children at school, especially children who have been given the opportunity by parents to play android by their parents at home. So interactive games are easier and fun.

Control groups that use powerpoint-based application games in children's reading ability seem monotonous and give little interest in children. In-game display-based powerpoint applications do not provide reciprocity in reading stimulation, children are required to remember commands that are only explained by the teacher at the beginning of the game. Game activities tend to make children guess what they should do in play. This results in only a few children who are able to read well and clearly because some children do not pay attention to teachers who teach in front and busy with other activities.

This causes the ability of reading of children in experimental class given treatment using interactive games based on inquiry learning model better than the result of the ability of reading in control class that using powerpoint application based game, can be seen from the average value of the children in the experimental group is higher than the mean value Average child in the control group. So it can be concluded that the use of interactive games based on inquiry learning model has an enormous influence on the ability of reading, and gives a pleasant impression for children.

\section{CONCLUSIONS AND SUGGESTIONS}

Based on the results of the analysis of research data that has been done, it can be concluded that the results of research conducted at Kindergarten in Padang, the results of the ability of reading children in experimental class (B1) conducted with interactive games based on inquiry learning model is higher than With control-grade children (B4) performed with application-based games (88) for the experimental class and (76.5) for the control class. In the hypothesis test, the result of tcount > ttable where 2,76442>2,10092 proved with significant level $\alpha 0,05$ this mean there is significant 
difference between the ability of reading in experimental class that use interactive game based on inquiry learning model with control class Using an app-based game. Thus, interactive games based on inquiry learning model proved to be influential in developing on the ability of reading for children in Kindergarten in Padang.

Based on the results of the above research, then put forward some suggestions as follows that the interactive gaming media based on inquiry learning model is expected to be used as an alternative media learning in developing early childhood reading skills for early childhood educators, so as to improve the quality of learning. To researchers who wish to continue this research is expected to apply it to larger groups or samples or apply it to develop children's reading skills.

\section{References}

[1] A. N. Cahyo, "Game Khusus Penyeimbang Otak Kanan dan Kiri Anak," Yogyakarta: Flashbooks, 2011.

[2] Y. Yulsyofriend and D. Suryana, "Pembelajaran Membaca Berbasis Teknologi Informasi di TK Pertiwi VI Kota Padang," 2011.

[3] D. S. Prasetyono, "Rahasia Mengajarkan Gemar Membaca Pada Anak Sejak Dini," Yogyakarta: Think, 2008.

[4] E. S. Muflikha, "Peningkatan Kemampuan Anak Mengenal Huruf Melalui Media Tutup Botol Hias di PAUD Kenanga I Kabupaten Pesisir Selatan," SPEKTRUM PLS, vol. 1, no. 1, pp. 18-32, 2013.

[5] R. Aizid, “Tips Ampuh Menyiapkan Anak Gemar Baca: Sejak Dalam Kandungan Sampai Masa Pengasuhan.” Yogyakarta: Diva Press, 2011.

[6] A. Susanto, Perkembangan anak usia dini: pengantar dari berbagai aspeknya. Kencana, 2011.

[7] D. Salma and E. Siregar, "Mozaik Teknologi Pendidikan," Jakarta: Penerbit Kencana, 2004.

[8] R. Nisak, "Seabrek games asyik-edukatif untuk mengajar PAUD/TK." Yogyakarta: Diva Press, 2011.

[9] P. D. Sugiyono, "Metode penelitian pendidikan," Pendekatan Kuantitatif, 2010.

[10] A. Suharsimi, "Prosedur penelitian suatu pendekatan praktek," Jakarta: Rineka Cipta, 2006.

[11] T. Musfiroh, "Bermain Sambil Belajar dan Mengasah Kecerdasan," Jakarta: Depdiknas, 2005.

[12] A. Brown, "Media use by children younger than 2 years." Am Acad Pediatrics, 2011. 